\title{
MYSTICAL DISTANCE IN D.H. LAWRENCE'S SHORTER FICTION: THE SPIRIT OF PLACE AND THE LANDSCAPES OF THE HEART
}

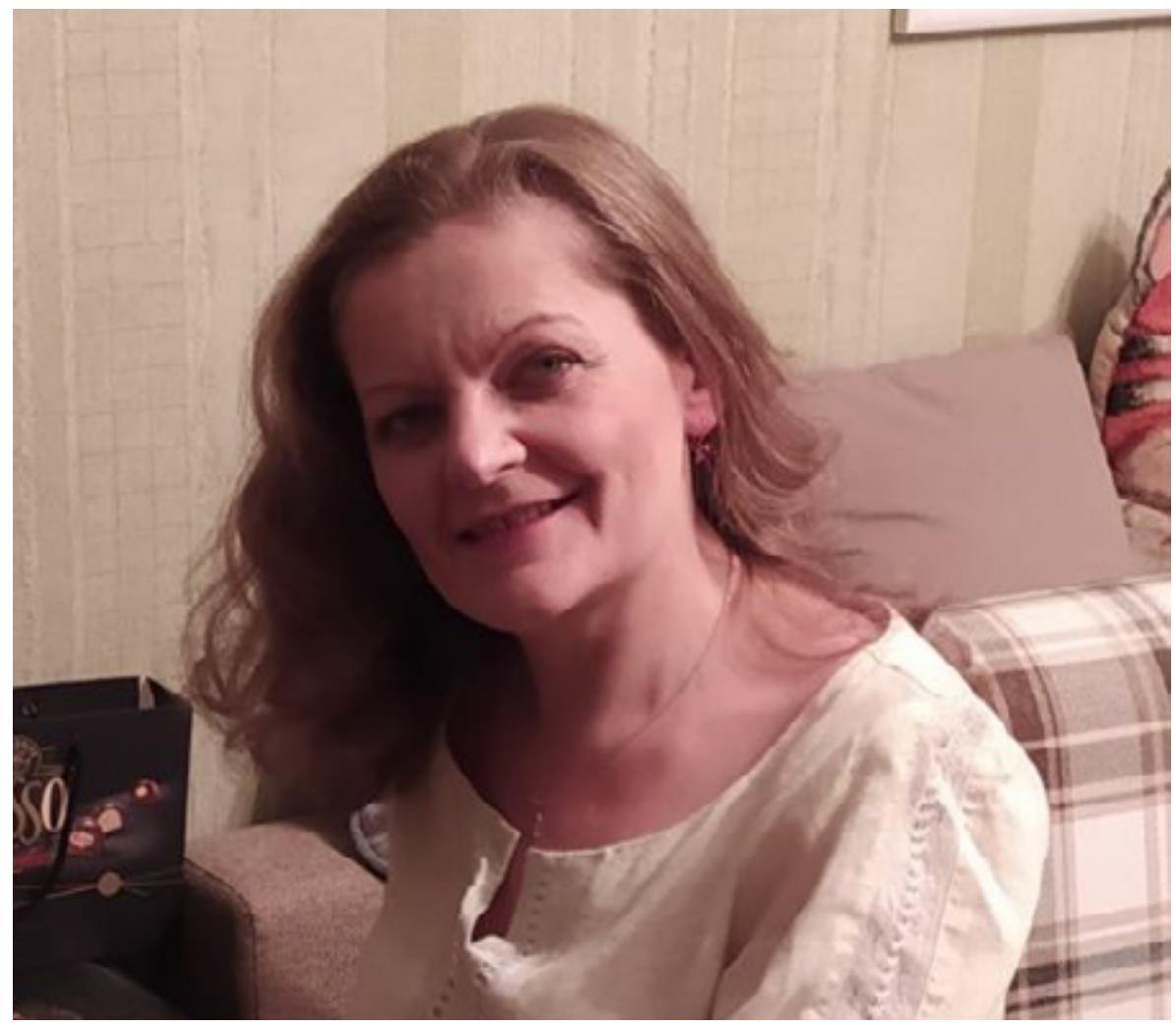

Marina S. Ragachewskaya

Habilitated PhD, Professor at Minsk State Linguistic University (Minsk, Belarus)

e-mail: marinaragachewskaya@gmail.com 
Astract. This article uses the Jungian archetypal theory to analyze a selection of shorter fictions by D.H. Lawrence (the novellas The Princess (1924), St Mawr (1925), The Woman Who Rode Away (1928), The Escaped Cock (1929) and a few short stories) where the enigmatic aspect of place and distance plays an important role in the narrative, character development and personality individuation. I single out four types of the mystical distance in D.H. Lawrence, and focus on the spatial aspect. The paper shows that each novella or short story treats "the spirit of place", albeit in a deferent light: the place may embody the Spirit, the Shadow, the Anima or Animus archetypes. Each travelling protagonist undergoes a spiritual transformation, which is presented in non-identical patterns, and the distance they cross bears the signs of the mystical. The place serves as the physical location of the quest, while the workings of the soul reveal such forms of spiritual and mystical aspects as Spirit-Animus, Spirit-Shadow, sacrifice and rebirth.

Key words: D.H. Lawrence, spirit of place, mystical distance, archetype, quest, shadow, transformation, SpiritAnimus, Spirit-Shadow. 
All art partakes of the Spirit of Place in which it is produced [SCAL: 167]

There's more things than we're aware of happening to us!" [GG: 13]

B esides crudely realistic pictures of miners' and multifaceted world with far-reaching insights, appropriating also the sphere of the mystical. Lawrence as the mystical preacher is the subject, of which scholars have good awareness. To intensify the sense of a mystical unity between humans and nature, Lawrence's characters, especially in novels and short novels, preach pantheistic philosophies (Lou in "St Mawr", or the protagonist in "The Woman Who Rode Away"). In short stories, however, with little space to do so, mysticism is evoked through plot techniques, peculiar imagery and symbolism.

In the 2001 article "Lawrence the Mystic", Stephen Taylor explored the notion of the "mystic", rightly pointing out that it refers to "irrational' phenomena which lie beyond the boundaries of modern science" [Taylor: 62]. The critic also offers the definition of the mystic applying the original meaning of the term - "a state of consciousness which is more intense or higher, than the normal state of consciousness which most people live in" [Taylor: 63]. This very concept is further elaborated in the article, showing that Lawrence can rightfully be associated with mystics. His view of the world and Self, perceived through ancient cults and religions, helps his characters to be mysteriously drawn and get infatuated with each other, for better or for worse, as it happens ubiquitously ("The Princess", "The Horse-Dealer's Daughter", "Love among the Haystacks" and numerous other texts).

The "mystic(al) prose / fiction" may apply to medieval texts, "testifying" of some highly religious experience, visions and revelations. But looking at authors like Edith Wharton, for example, Lawrence's contemporary, we can work out another definition: it is a kind of prose fiction which describes mysterious happenings, often involving inexplicable coincidences of a mystical nature, but do not contain other "classically gothic" elements. The encounters with the strange and irrational are presented as "facts" of life in no need of further explanation and are to be taken for granted. Mystical instances may involve almost impossible coincidences, good / bad luck, deeds of presumable spirits, which are not revealed to the reader's eye. The most salient cases of the macabre / ghost stories by Lawrence were collected in a volume The Collected Supernatural and Weird Fiction of D. H. Lawrence (2009): "Glad Ghosts", "Smile", "The Last Laugh", “The Lovely Lady", “The Man who Died”, “The Border Line", "Sun", "The Woman who Rode Away" and "The Rocking Horse Winner".

By the "mystical distance", I shall mean a sort of gap between what can appear to be present and what is materially tangible and can be seen, felt or touched. Thus, Lawrence the mystic and 
the mystical quality in his shorter fiction need to be set apart in this sense, and I shall consider this "mystical distance" in selected novellas and short stories. It is possible to single out at least four varieties of a mystical distance in Lawrence. First, it is the kind of distance C.G. Jung termed "synchronicity": the distance in time and space between two phenomena meeting through some "acausal connecting (togetherness) principle," "acausal phenomena" or "meaningful coincidence of two or more events where something other than the probability of chance is involved" [Jung, V 8: 428]. In the final volume (14), dedicated to the mystical, he refers to that previous research.

Lawrence's stories, such as "Shadow in the Rose Garden" (1914), for example, reveal that "meaningful coincidence". In it, a young woman, who has not been married long, comes across her former lover, a military man, who is a lunatic now, and who therefore fails even to recognize her: "She sat and heard him talking. But it was not he. Yet those were the hands she had kissed, there were the glistening, strange black eyes that she had loved. Yet it was not he" [SSS: 74]. The scene that describes this mystical coincidence while keeping a distance between the past and the present, takes place in a rose garden, which is a kind of portal into the past, and a symbol of love. This coincidental encounter is mystical in a sense it is portrayed as something synchronic and meaningful, quite likely, but also of little probability.
The second type of "mystical distance" is when someone's good or bad luck is attributed to supernatural forces. It is best represented in "Glad Ghosts" (1926) and "The Rocking Horse Winner" (1926). Characters speaking of ghosts as if they were flesh-and-blood presences, "a more intense or higher" state of consciousness, and an enlightening, albeit edifying outcome are peculiar features of this type of mystical stories.

In "Glad Ghosts", the untypical first-person narrator happens to act as a sort of medium who, through a very ambiguous "encounter" with a family ghost restores "good luck" and brings rebirth to the dead relationships in two families. This short story is Lawrencian only in the sense that it blends into the mystical plot the overt sexual connotation. Two married couples - Luke and Carlotta Lathkill, and Colonel Hale and his meek and impersonal shadow of a wife - are unhappy. Tolstoy's first lines from Anna Karenina are to the point here: "Happy families are all alike; every unhappy family is unhappy in its own way". Mr Lathkill's dynastic curse is always at his heels, and their three children die. The Colonel, from the other couple, is forced to obey the ghost of his deceased wife, Lucy, poor neglected type of a devoted spouse, which keeps haunting Mr Hale "forbidding" to even touch his new Mrs Hale. However, both couples apparently share the same disease - not being good to each other in their bodies. Bad luck, as Mr Morier preaches to them, is somewhere deep inside 
us, not hovering above in the ghost shape. Luke begins to understand it, too:

“'Do you know', he said, 'I suddenly thought at dinner-time, what corpses we all were, sitting eating our dinners. I thought it when I saw you look at those little Jerusalem artichoke things in a white sauce. Suddenly it struck me, you were alive and twinkling, and we were all bodily dead. Bodily dead, if you understand. Quite alive in other directions, but bodily dead. And whether we ate vegetarian or meat made no difference. We were bodily dead"' [GG: 22].

The mystical distance that the story creates is between that very "heightened state of consciousness" that $\mathrm{Mr}$ Morier, the narraror, achieves sleeping in the special "ghost-room" and his initial skepticism:

"And I must have gone far, far down the intricate galleries of sleep, to the very heart of the world. For I know I passed on beyond the strata of images and words, beyond the iron veins of memory, and even the jewels of rest, to sink in the final dark like a fish, dumb, soundless, and imageless, yet alive and swimming. And at the very core of the deep night the ghost came to me, at the heart of the ocean of oblivion, which is also the heart of life. Beyond hearing, or even knowledge of contact, I met her and knew her. How I know it I don't know. Yet I know it with eyeless, wingless knowledge" [GG: 28].

This resonates strangely with some later $20^{\text {th }}$-century European studies of the mystical state of consciousness, namely, Colin Wilson's book Superconsciousness (2009). Wilson identifies eight levels of consciousness, the highest one, the $8^{\text {th }}$, being "the mystical consciousness", "which seems to contain a series of paradoxes, such as 'I am nothing and everything', etc. [Wilson: 206], which for Mr Morier is "beyond hearing, or even knowledge of contact, I met her and knew her. How I know it I don't know" [GG: 28].

While "Glad Ghosts" ends in comedy - the picture of two happy families now, one of which is engaged in raising pigs (!), "The Rocking Horse Winner" is essentially tragic. The mystical distance in the story's space lies between the material side of good luck and the dark, strange, intangible "knowing". A young boy Paul, sensing constant lack of money and "bad luck" in the family, starts riding his toy-horse, to the point of the clairvoyant state, after which he bets on the horses in races he know will win. This mysterious "knowing" brings a huge fortune to his mother, but also the boy's death. "And even as he lay dead, his mother heard her brother's voice saying to her, 'My God, Hester, you're eightyodd thousand to the good, and a poor devil of a son to the bad. But, poor devil, poor devil, he's best gone out of a life where he rides his rocking-horse to find a winner"' [OOC: 218].

Thirdly, the mystical quality enters a number of short stories (and novellas) through an object which is also a symbol (a doll, a fox, a horse, a thimble, a rooster, etc.). The novellas collected by Penguin into a single volume in 1982, are 
marked by a touch of the mystical. As J. Hawthorn notes, there is "the use of magic; and the visionary ending..." [Hawthorn: 116]. There is always a character who strives for self-assertion by means of power, and this strife induces him into the higher state of consciousness. The symbolic object acquires the mystical role of a conductor into that state. Such an object performs this role in the short story "The Thimble" (1917) and the novella "The Ladybird" (1923). The short story offers a more focused perception of the mystical distance between what appears (utter separation of souls after the mutilation by war) and what is immediately seen (the inanimate reality that speaks no language but bears tangible vibrations):

"Her right hand came to the end of the sofa and pressed a little into the crack, the meeting between the arm and the sofa bed. Her long white fingers pressed into the fissure, fissure, pressed and entered rhythmically, pressed and pressed further and further into the tight depths of the fissure, between the silken, firm upholstery of the old sofa, whilst her mind was in a trance of suspense, and the firelight flickered on the yellow chrysanthemums that stood in a jar in the window. ... It was a thimble set with brilliants..." [CSS: 565].

Finally, the mystical distance arises between a place, an expanse to be crossed, and the spiritual landscape of a traveller. Lawrence's fascination with place evolves throughout his writing. In whatever setting Lawrence puts his characters, that setting exercises certain power on the heroes. The initial lines of Lawrence's first novel The White Peacock (1911) relate the narrator's keen awareness of the place that "seemed old, brooding over its past" [WP: 1] and endow the landscape image with the mystical spiritual qualities. The awareness of place becomes, with the evolution of the author's prose, artistically better integrated and filled with the writer's ingrained thought and message. Thus, in Sons and Lovers (1913), for example, there is a picturesque representation of the gardens, woods and the farmland, while the traditional opposition between the natural and the mechanical makes a conscious appeal to the reader. This opposition motif is preserved in the later works, but there is a noticeable evolution in the depiction of place, which transcends the characters' souls more and more intensely. As Mark Deggan suggests, “D.H. Lawrence's novel, Kangaroo, transforms the topographical actuality of its landscapes into the interior topology..." [Deggan: 87]. To quote Jack Stewart to the same effect, "For Lawrence, 'place' is a sensory / imaginative complex of surface and depth, vision and detail" [Stewart: 153].

Lawrence's preoccupation with place reaches its apogee - in terms of metaphorical actualization - in the short novels, or otherwise called also novellas (especially in The Princess (1924), St Mawr (1925), The Woman Who Rode Away (1928) and The Escaped Cock (1929)), where each setting possesses its own symbolic and archetypal meaning. Jeremy Hawthorn summa- 
rized Lawrence's novellas as being "very close to formula," i.e., containing "repetition of certain elements", "general animal analogy", "disordered relationships", "the opposition of traditional love and a new kind of relationship between the sexes", "the use of magic; and the visionary ending..." [Hawthorn: 116]. Immediately preceding the writing of the novellas, Lawrence composed his much-acclaimed Studies in Classical American Literature (1923). It is in these essays that the author explores the cryptic nature of place. In particular, Lawrence writes:

"Every continent has its own great spirit of place. Every people is polarized in some particular locality, which is home, the homeland. Different places on the face of the earth have different vital effluence, different vibration, different chemical exhalation, different polarity with different stars: call it what you like. But the spirit of place is a great reality" [SCAL: 17].

\section{As Maria Cristina Consiglio notices,}

"The spirit of place should not be understood as something superficial, external, or natural, that is as something simply defining the territory of a given place. Rather, it is the very soul of the place, what differentiates it from all the other places on earth and has influenced behavior, attitudes, beliefs, the practices of the people inhabiting it" [Consiglio: 112].

In this paper, with the help of the Jungian archetypal approach I seek to establish the mystery of the topoi "outside England" (such as New Mexico) that bear an almost magical quality in some selected texts by Lawrence. Following my earlier ecocritical research into Lawrence's landscapes, I explore their parallelism with emotional education. The landscapes in the short novels are the places shaped by forces from inside and outside: they are products of objective visual perception as well as the characters' momentary perception coloured by personal feelings and thoughts. In his essay "The Two Principles", Lawrence considers not just the abstract, detached power of natural elements, but something more profound: "We need to find some terms to express such elemental connections as between the ocean and the human soul" [SCAL: 260]. A critical tool to help infer the nature of such mystical connections might well be an archetypal approach.

Jungian analysis is not an alien sphere to Lawrence's studies. Graham Hough points out, that Lawrence was often trying to express C.G. Jung's widely known integration concept, "a process which involves displacing the centre of the personality from the ego-consciousness to a new centre whose circumambient circle includes the whole unconscious" [Hough: 173]. Keith M. May considers the kinship between Lawrence and Jung to be "partly due to the period of social and philosophical history in which both men worked; that is a period fundamentally characterized by the shocking discovery ... of the 'dark' side of man's nature" [May: 47]. Daniel J. Schneider argues, that "in reaction to modern literature, 
both Jung and Lawrence call for a new balance, a compensating emphasis on feeling; and both view the unconscious as being inherently compensatory" [Schneider: 254]. Lawrence did read Jung in translation, namely his work Psychology of the Unconscious (first published in German in 1912), the title of which appears as an intertextual reference in Lawrence's own essay on psychoanalysis Psychoanalysis and the Unconscious (1921). Lawrence loosely refers to Jung in his attack on the psychological science: "Jung dodges from his university gown into a priest's surplice till we don't know where we are" [FUPU: 19]. In his letter to Mabel Dodge, he says:

"Jung is very interesting, in his own sort of fat muddled mystical way. Although he may be an initiate and trice-sealed adept, he is soft somewhere, and I've no doubt you'd find it fairly easy to bring his heavy posterior with a bump down off his apple cart" [Letters: 540].

We must sometimes ignore these poignant and even bitingly sarcastic comments of a religious adept of some unique kind, like Lawrence, and view realistically the vital concordances between Lawrence and Jung, which have prompted a number of scholars' research, such as Sandra Gilbert's analysis of the Jungian-Lawrentian "Great Mother", the mentioned piece by K.M. May, as well as some recent papers.

A Jungian reading universalizes a fictional text and brings about the awareness of human missions and possibilities. The four novellas mentioned above are built to represent the quest archetype; in each case, there is a clearly outstanding traveler, undertaking a journey (both physically and in spirit): Lou in St Mawr, the Princess, the Man Who Died and the Woman who rode away. There is a vivid motif of travelling away from home, crossing a kind of mystical distance and completing the journey with a distinct acquisition of "treasure", of a spiritual kind (predominantly for the reader, in fact).

A Jungian analysis anticipates that the quester must travel to the edge of human 'comfort' (originally, in mythology, it was supposed to be the top of a mountain, deep within a cave or the ocean, far into the wilderness or into the woods, down into the abyss, or even become ravished up to Heaven), where the seeker will encounter something fantastic, either the divine or the infernal. In Lawrence's novellas, the questers do reach that point on the physical landscape: a cave high up in the mountains (The Princess), the distant exotic deserts of New Mexico plains (St Mawr), the lost and unreachable Indian village and a mountain cave there as well (The Woman Who Rode Away), and the truly mythological chronotopes with Egyptian flora and scenery (The Escaped Cock). The seeker is supposed to return with a treasure, which varies from valuables and riches to invaluable spiritual knowledge. Often, especially in the case of a failed quest, there must be sacrifice. However, the utmost goal of a quest is individuation - the processes of singling one's individual consciousness out of the collective unconscious. 
The purpose may also be initiation. Personality individuation involves integration of the rejected, inferior side of one's life into one's total experience and taking responsibility for it.

These novellas fit into a Jungian circle-scheme, in which the outer circle stands for the movement through the landscape, marking all the meaningful obstacles and trials, as well as significant meetings en route, while the inner circle serves as a reflection of the external phenomena in the form of archetypes - mental forms shared by the collective unconscious. These two circles create that very mystical distance. The "outlandish" ranchos, the Indians' pueblos, the surrounding mountains and the allegedly Egyptian vista of The Escaped Cock - all function as archetypal Anima, Animus, Spirit and Shadow.

The poetics of each selected text conjoins male and female landscape imagery (hard rock and wood - and soft fields and streams), the Spirit wisdom of mother Nature (embodied in the elements and mysterious unconscious revelations that the characters experience) - and the dark, imminent forces of the natural landscapes which exert an almost uncanny Shadow influence on such characters as the Princess and the Woman who rode away.

It is curious to discover how individuation occurs in each story, and how the fulfillment of the quest is different. Lawrence's novellas begin with loneliness, despair, agony, lost state of mind, longing for something yet to be seen. Lou Carrington "did not quite belong", Lawrence says, to the English landscape and was dimly aware of other mysterious things in existence; the Princess felt a vital need to travel, after her father's death; the Man Who Died was rushed by the need to escape from the life which had tired him so much; and the nerves of the Woman who rode away "began to go wrong: she must get out. She must get out" [WWRA: 40].

\section{The mystical distance covering in St Mawr}

As numerous analyses of St Mawr suggest, there is hardly any unanimity as to its central message. Frank Raymond Leavis called it a dramatic poem, "a creative and technical originality more remarkable than that of The Waste Land" [Leavis: 271]. Gemma Moss remarks that "it is usually addressed in terms of Lawrence's encounters with otherness and difference, as well as his broader critique of industrialization" [Moss: 119]. I am looking at the quest-related landscape imagery, which, rather surprisingly for Lawrence, comes into full view of the narration only with the characters' arrival in New Mexico and fully captures the narrative space. The plot lacks coherence; it is rather like a chain, a procession of different characters, where Lou's quest is postponed until almost the end of the novella. The main hero, however, seems to be the horse - so remarkable is his presence and personification. At the beginning of the story, Mrs Witt and her daughter Lou are represented as dissatisfied, disappointed, and resentful of men. The horse, on the contrary, is given antithetical qualities: aspir- 
ing towards vitality, freedom and wild determination to explore the world around him with proud independence. Thus a certain motif of women without men (or, rather, the deficiency of pure womanhood) lacking the psychic component of the Animus is established. One third of the story somehow manages on a queer combination of irony directed against human characters, deep sarcasm of society and sporadic wonder about the mystery of St Mawr. Louisa "didn't 'belong' anywhere" [CSN: 276], and, "having one's own way landed one completely at sea" [CSN: 276]. Mrs Witt is shown as a domineering female type, who "kept track of everything, watching, as it were, from outside the fence, like a potent well-dressed demon, full of uncanny energy and a shattering sort of sense" [CSN: 279-280]. Rico is an ironic representative of modern civilised life: "handsome, elegant, but mostly he had spots of paint on his trousers" [CSN: 277].

There has been much speculation as to the significance and symbolism of the horse-figure. Lou's sense of the failure of her marriage is brought to full consciousness by St Mawr. Rico's deficiency and non-correspondence with the Animus archetype is also played up by St Mawr. Margaret Storch brilliantly outlined this idea:

"Lou Witt ...has rejected only the society of men and artists of the type whom Lawrence would renounce as effete and spiritually starved. Two strong images of male potency, the Celtic man Lewis and the gleaming red horse St Mawr, both function in the novel as true male forces who merit the respect of women, by contrast with Rico and his associates. They vanish from the narrative in the later part of the novel because they have become unattainable ideals" [Storch: 54-55].

Both Lou and the horse keep away from the opposite sex. As everywhere in the novellas, an animal symbol accords with erotic desires. This is how Lawrence describes St Mawr: “... a handsome bay horse with his clean ears pricked like daggers from his naked head" [CSN: 284]; “... she was startled to feel the vivid heat of his life come through to her, through the lacquer of red-gold gloss. So slippery with vivid, hot life!" [CSN: 286].

St Mawr represents maleness, but of a specific nature, because he is not "keen on the mares": his presence in Lou's life makes her wrap up her femininity and start looking for something she describes as a different sort of "tank" "to get our lives straight from the source, as the animals do" [CSN: 321]. The fairytale quality of this novella (as well as of the other three) hints at the Jungian assumptions about the meaning of the central figure even more emphatically. Who and what is St Mawr? Why does he disappear with the journey's end? Jung wrote: "In myths and fairytales, as in dreams, the psyche tells its own story, and the interplay of the archetypes is revealed in its natural setting as formation, transformation / the eternal Mind's eternal recreation" [Jung, V 9/1: 217]. Lou's transformation is what her journey ends up with: "It's the beginning of something 
else, and the end of something that's done with. I know, and there's no altering it, that I've got to live differently" [CSN: 425-426].

Hence, the merging, the dissipation of the horse in the New Mexico setting is his alleged reunion with the spirit of place. Like many fairytales, where the presence of the image of Spirit is usually represented by a Wise Old Man, Lawrence's novella begins to make sense if we consider St Mawr to be the figure-condensation of the Animus and the Spirit, or the natural wisdom, which is, however, neither good nor evil, but is simultaneously both. Jung speculates that

“... again and again in fairytales we encounter the motif of helpful animals. These act like humans, speak a human language, and display a sagacity and a knowledge superior to man's. In these circumstances we can say with some justification that the archetype of the spirit is being expressed through an animal form" [Jung, V 9/1: 239].

The double nature of archetypes, according to Jung, is "a positive, favourable, bright side" and a "partly negative and unfavourable, partly chthonic", and so "the spirit archetype is no exception" [Jung, V 9/1: 226]. The explanation of the evil quality perceived in St Mawr, malicious, vile and inflicting injuries, as well as the explanation of Lou's vision of evil with the image of the horse upturned, the "hoofs working wildly" [CSN: 341] may be coherent with Jung in mind. "True, writes Jung, the archetype of the spirit is capable of working for good as well as for evil, but it depends upon man's free - i.e., conscious decision whether the good also will be perverted into something satanic" [Jung, V 9/1: 253]. According to Jung,

"[T]he description of our archetype would not be complete if we omitted to consider one special form of its manifestation, namely its animal form. This belongs essentially to the theriomorphism of gods and demons and has the same psychological significance. The animal form shows that the contents and functions in question are still in the extrahuman sphere, i.e., on a plane beyond human consciousness, and consequently have a share on the one hand in the daemonically superhuman and on the other in the bestially subhuman" [Jung, V 9/1: 230].

Lou seems to acquire the treasure of wisdom, which, in Jung's terms, "seeks the middle path" between human sense of inferiority to nature and arrogance, which has to be paid for through the "affinity with daemon and beast" [Jung, V 9/1: 230-231].

The landscape represents this wisdom of "great" and "splendid" unity, which Lou finally acquiesces: "The landscape lived, and lived as the world of the gods, unsullied and unconcerned. The great circling landscape lived its own life, sumptuous and uncaring. Man did not exist for it" [CSN: 417].

The strange sort of journey being over, and, voila, Lou admits to actually being loved by the 
spirit of place. The remarkably emotive and revelational passage testifies to the treasure obtained, which is self-knowledge, the ability to merge with nature and the transcendent Spirit-Animus:

"There's something else even that loves me and wants me. I can't tell you what it is. It's a spirit. And it's here, on this ranch. It's here, in this landscape. It's something more real to me than men are, and it soothes me, and it holds me up. I don't know what it is, definitely. It's something wild, that will hurt me sometimes and will wear me down sometimes. I know it. But it's something big, bigger than men, bigger than people, bigger than religion. It's something to do with wild America. And it's something to do with me. It's a mission, if you like. I am imbecile enough for that! - But it's my mission to keep myself for the spirit that is wild, and has waited so long here: even waited for such as me. Now I've come! Now I'm here. Now I am where I want to be: with the spirit that wants me. ... It needs me. It craves for me. And to it, my sex is deep and sacred..." [CSN: 427].

It seems Lawrence really advocates the life he cannot seriously recommend. Therefore, as a modernist fairytale, the novella is about a beauty coming to the beast, soon to be rewarded with fulfillment, even though, as Lou's mother ironically observes, she will spend her life keeping to herself. She has come dangerously close to the knowledge of her own Animus-Spirit. Thus, the mystical distance in this novella is covered by a quest to unite the Spirit of place and the yearning of the soul.

\section{The mystical distance between the inner and outer "demons" in The Princess}

In The Princess, Lawrence's exploration of the Animus archetype includes a fictional speculation on virginity. The roots of this kind of virginity, rather perverse and deficient in itself, lie not in the pitiful non-enriching experience of a female protagonist in relationships with men, as is the case of the previous novella, but in an endless, fatal attachment of the heroine to her father. However, as Jung writes,

"[T]he animus does not appear as one person, but as a plurality of persons... The animus is rather like an assembly of fathers or dignitaries of some kind who lay down incontestable, 'rational', ex cathedra judgments. On closer examination these exacting judgments turn out to be largely sayings and opinions scraped together more or less unconsciously from childhood on, and compressed into a canon of average truth, justice, and reasonableness, a compendium of preconceptions which, whenever a conscious and competent judgment is lacking (as not infrequently happens), instantly obliges with an opinion. Sometimes these opinions take the form of so-called sound common sense, sometimes they appear as principles which are like a travesty of education: 'People have always done it like this', or 'Everybody says it is like that"' [Jung, V 7: 207].

The Princess learned these lessons of pre-established opinions rather early in her life, the major one being the lesson of distancing herself from the world of other men. The postulates of 
the Animus ("The man seemed a property of her own mind rather than a thing in himself, another being" [CSN: 437]), strong unshakable authority that has a mortal grip on the Princess' worldview, also predetermine the limitations imposed on her perception of, attitude to and relations with men. Thus, the father, in fact, warns his too-much-cherished daughter that "inside everybody there is another creature, a demon that doesn't care at all... And the green demon never changes... and this demon is a man's real self..." [CSN: 431]. The description of the demon correlates with the Jungian Shadow. However, while for Jung, the recognition, acceptance and transformation of one's Shadow is the prerequisite of a healthy development of the Self, the Princess - Dolly Urquhart - is inhibited from the action. The journey she undertakes with her female companion, "the obvious thing to do, of course" [CSN: 437] after her father's death, is the quest in search of marriage (the stated reason to go) in the less vulgar South-West - New Mexico, of marriage, which is, however, very much "in the abstract" [CSN: 437]. It is an archetypal quest for a husband, which results in something completely opposite.

The Rancho del Cerro Gordo is a place that fits the definition of a topos suitable for the quester when he / she leaves the habitual surrounding to search for the treasure quite at "the end of the world": "The ranch lay by a stream on the desert some four miles from the foot of the mountains..." [CSN: 437-438]. A curious detail about the only male creature who is capable of fascinating her - Domingo Romero - is that he is "almost imperceptible in the landscape" [CSN: 440]. Here, unlike in the previous novella, the dark demon, the Shadow, is projected onto the landscape and almost dissipates in it.

The Princess' journey through the landscape has a stopover on a "rock over a quiet pool" [CSN: 440] to fish. The outer, physical circle in the Jungian quest features "the bristling wild canyon" [CSN: 440], while the inner self is able to distinguish the "fine" type of demon in Romero, by her father's definition. It looks as though the landscape journey and the journey inside the Self are perfectly reflexive of each other.

As if it were a development event in a fairytale plot, the Princess is eager to see large animals high up in the mountains - a bear or a deer. Jung writes in this respect:

"It seems to me more probable that this liking for diminutives on the one hand and for superlatives - giants, etc. - on the other is connected with the queer uncertainty of spatial and temporal relations in the unconscious" [Jung, V 9/1: 224].

The desire that overtakes the Princess borders on that confused sense of proportion, which Lawrence refers to as "madness": "She wanted to look over the mountains into their secret heart... She wanted to see the wild animals move about in their wild unconsciousness" [CSN: 444]. However, this remains a distance she cannot cross so far. 
It becomes clear with the development of the plot, that absolute virginity of the body and soul does not give vent to the dark waves of the true blood-desires. Lawrence expands the notion of virginity, makes it a metaphoric, even a philosophical notion, attributing this feature to nature and the landscape. The scene where Romero and the two women set off on a journey is a powerful metaphoric rendering of the meeting with one's own Shadow:

"They wound into blue shadow, then up a steep stony slope, with the world lying pallid away behind and below. Then they dropped into the shadow of the San Cristobal canyon. The stream was running full and swift. Occasionally the horses snatched at a tuft of grass. The trail narrowed and became rocky; the rocks closed in; it was dark and cool as the horses climbed and climbed upwards, and the tree trunks crowded in the shadowy, silent tightness of the canyon. They were among cottonwood trees that ran straight up and smooth and round to an extraordinary height. Above, the tips were gold, and it was sun. But away below, where the horses struggled up the rocks and wound among the trunks, there was still blue shadow by the sound of waters and an occasional grey festoon of old man's beard, and here and there a pale, dripping cranesbill flower among the tangle and the débris of the virgin place. And again the chill entered the Princess's heart as she realized what a tangle of decay and despair lay in the virgin forests" [CSN: 446-47].

Thus, the epithet "virgin/al" acquires a bleak colouring, deprives the object of its chastity.
However, the virginity that strives for the perverse preservation of itself, clashes against a contrary desire - almost erotic, but unconscious within the Princess, and this desire is reflected on the outward line of the Jungian circle:

"For high up, away in heaven, the mountain heights shone yellow, dappled with dark spruce firs, clear almost as speckled daffodils against the pale turquoise blue lying high and serene above the dark-blue shadow where the Princess was. And she would snatch at the blood-red leaves of the oak as her horse crossed a more open slope, not knowing what she felt" [CSN: 447].

The piece of the scenic description of the canyon is the bare slope "where the mountain ended against the sky" [CSN: 451], and "fairy-like gentleness" basking in bright yellow colours against the clear blue sky. And as she moves further upwards, accompanied by two Indians away on hunting,

"[I]n front now was nothing but mountains, ponderous, massive, down-sitting mountains, in a huge and intricate knot, empty of life or soul. Under the bristling black feathers of spruce near by lay patches of white snow. The lifeless valleys were concaves of rock and spruce, the rounded summits and the hog-backed summits of grey rock crowded one behind the other like some monstrous herd in arrest. It frightened the Princess, it was so inhuman. She had not thought it could be so inhuman, so, as it were, anti-life. And yet now one of her desires was fulfilled. She had seen it, the massive, 
gruesome, repellent core of the Rockies. She saw it there beneath her eyes, in its gigantic, heavy gruesomeness" [CSN: 454].

Travelling to the edge of comfort must inevitably bring around strange encounters and acquisition of treasures. Here, among the "kneeling" mass of the mountains, the Princess encounters her own Shadow, embodied in the figure of Romero - "Strange and ominous, only the demon of himself" [CSN: 455]. Remembering the limitations in the Animus figure for Princess, we may suppose that Romero is also the representation of the hidden aspects of it. Jung comments on the "figures from the dark hinterland of the psyche", stating that they "can assume an almost inexhaustible number of shapes, enough to fill whole volumes..." [Jung, V 7: 210]. He explains: "The autonomous complex of anima and animus is essentially a psychological function that has usurped, or rather retained, a 'personality'... They cannot be integrated into consciousness while their contents remain unknown" [Jung, V 7: 210].

The Princess, because of the inhibiting nature of her self-asserting will, cannot integrate the new aspects of the Animus into her consciousness. "She wanted warmth, protection, she wanted to be taken away from herself. And at the same time, perhaps more deeply than anything, she wanted to keep herself intact, intact, untouched, that no one should have any power over her" [CSN: 461]. No compromise, as Law- rence demonstrates, is possible within a woman with such a strong will and an impregnable mark of virginity. The battle of wills proves destructive. Romero "was exulting in his power over her, his possession, his pleasure" [CSN: 462]. Yet she strives to regain her ego and asserts it in her rebuff to Romero: "You think you can conquer me this way. But you can't. You can never conquer me" [CSN: 466]. The victory of the virginal will is absolute: "He stood arrested, looking back at her, with many emotions conflicting in his face wonder, surprise, a touch of horror, and the unconscious pain that crumpled his face till it was like mask" [CSN: 466].

A woman possessed by the Animus, according to Jung - and the Princess is possessed by a sturdy, impenetrable and unshakable Animus in her father's psychic embodiment - "is always in danger of losing her femininity, her adapted feminine persona, just as a man in like circumstances runs the risk of effeminacy. These psychic changes of sex are due entirely to the fact that a function which belongs inside has been turned outside. The reason for this perversion is clearly the failure to give adequate recognition to an inner world which stands autonomously opposed to the outer world, and makes just as serious demands on our capacity for adaptation" [Jung, V 7: 209].

The resulting "treasure" of the quest in the novella remains forever buried together with the dead body of Romero. While the Princess was able to recognize the positive aspect of the 
Demon in him and the reflection of that demon as her Shadow, she proves unable to reconcile it with her own Anima. The landscape, therefore, bears unmistakable signs of shadowiness and virginity, but no fulfilling aspects of the wisdom Spirit. Thus mystical distance between the inner and outer "demons" remains uncovered.

\section{The mystical distance in The Woman Who Rode Away}

The mystical distance between life and death made dangerously short in The Woman Who Rode Away. The aura of negative criticism that surrounds the text of The Woman Who Rode Away has been possible due to the condition the main character endures: a drugged and captive woman being prepared for the sacrificial execution. As such, the novella easily subjects itself to a moralistic vein of interpretation. I rather side with the critics who refuse to view it as a deviation or a weird and desperate premortem fantasy. To quote Barbara Ann Schapiro: "Interpretations that stress only the devaluation and objectification of the woman - the perspective of the Indians - miss the Woman's own perspective from which the major part of the story is indeed told" [Schapiro: 69]. The Woman in the novella is strangely possessed by what she fears. As Juliette Feyel points out, "Lawrencian initiatory travel leads to an experience of intense vitality; nevertheless, some characters seem strangely attracted to what they fear whereas others reject what might make them much happier" [Feyel: 108].
The Woman's quest is impelled by her deep dissatisfaction with the pervasive deadness in life: "sundried dead church, the dead portales, the hopeless covered market-place, .... a dead dog" [WWRA: 39]. So the journey for death, or sacrifice, seems to restore the balance: to bring some life into death itself. Reading the novella as a modernist fairytale elucidates its intrinsic meaning, and the landscape highlights this meaning. In addition to the argument that through the integration of the four elements water, air, then fire, and finally earth - the novella brings about the cosmic unity and non-human fulfilment of the cosmic-ecological harmony [Ragachewskaya: 51], I see the workings of the landscape as indicative of a Night-Sea Journey "a kind of descensus ad inferos - a descent into Hades and a journey to the land of ghosts somewhere beyond the world, beyond consciousness, hence an immersion in the unconscious" [Jung, V 16: 455]. In the novella, it is embodied as a sort of the Jungian imprisonment, dismemberment and abduction. For Jung, such a regressive movement of energy harbours potential progression.

This heroine embodies a cosmic law uniting the male and the female elements with the three hypostases of the surrounding world: planetary-cosmic, biological (humans, animals and the plants) and temporal (life and death). The comment Leo Salter applied to his study of Lawrence as "the poet of Nature" is also true of Lawrence as an ecocritical philosopher: "...it is entry to the transcendent experience of nature 
that leads to knowledge of the god-like rather than the reverse" [Salter: 182]. This knowledge which Lawrence mythologizes in the novella is not intellectual, but unconscious, which equates it to a sort of initiation. As such, its price is supreme, and it is human life: "What difference does it make, the transition from the dead I am to the dead I shall be, very soon!" [WWRA: 68]. As all the Night-Sea-Journey myths derive from the perceived behavior of the sun, so the Woman is put in a symbolic relationship with the sun, which is "angry" in the sky. This Night-Sea Journey brings hope of resurrection. Peter Balbert, juxtaposing the modern and ancient (Chilchui) worlds, finds the Woman's redemptive quest inherently meaningful despite problematics in both worlds, and admits the main character's "final knowledge" about Chichui as "the practitioners of an underworld devotion..." [Balbert: 125]; and Laurie McCallum distinguishes the protagonist as a "sacralized sacrifice": "The Woman has transcendent status" [McCallum: 232, 240]; focusing on the significance of ancient ritual. The mystical distance in this novella becomes completely extinct; as the physical distance is covered, the distance between life and death meets in one point.

\section{The mystical distance between death and rebirth in The Escaped Cock}

The Escaped Cock is yet another quest, which can be regarded as the archetype of rebirth. Jung developed this theme in his work The Archetypes and the Collective Unconscious, where he defined five types of rebirth - metempsychosis, reincarnation, resurrection, rebirth proper and participation in the process of transformation. The implied Christ figure of the novella The Escaped Cock undertakes, in Jungian terms, a quest: from the life of giving, to death, and back to a new life, the life of the body as a compensation of the lost self. All necessary components of the quest are here: a quester, a place to go, a stated reason to go there, challenges and trials en route, and a real reason to go. The type of a rebirth quest is multifaceted: it involves resurrection, or the re-establishment of human existence after death, involving change and transformation of one's being; rebirth as renewal within the span of one's individual life involving the healing of some parts of personality; and participation in the process of transformation, which involves the changing of atmosphere, mentality and political order.

Here, as well as in The Woman Who Rode Away, Lawrence's traditional ironic outset is missing. There is seriousness and a certain sort of serenity pervading the narrative. The quester sets out on a journey which was impelled by his death. The first phase corresponds to separation, the separation from the world, as the Man Who Died avoids the noise of the human world on his way. The stated reason for the quest is to be "away from the city" [CSN: 558]. The real reason is to unite the spiritual and the sensual. "Strange is the phenomenal world, dirty and clean together! And I am the same. Yet I am apart!” [CSN: 572], 
exclaims the Man Who Died, thus proclaiming fusion of the opposites.

Sexual and natural imagery are inextricably intertwined in the climax. Each is a metaphor of the other, for it is their inter-involvement that the story embodies:

"But the man looked at the vivid stars before dawn, as they rained down to the sea, and the dog-star green towards the sea's rim. And he thought: How plastic it is, how full of curves and folds like an invisible rose of dark-petalled openness, that shows where dew touches its darkness! How full it is, and great beyond all gods. How it leans around me, and I am part of it, the great rose of Space. I am like a grain of its perfume, and the woman is a grain of its beauty. Now the world is one flower of many-petalled darknesses, and I am in its perfume as in a touch" [CSN: 597].

The focus on the landscape becomes prominent only with the arrival of the Man Who Died in an allegedly Egyptian peninsula:

"In the morning the coast was still chill in shadow, though the sun was up behind the hills, when the woman came down from the villa towards the goddess. The sea was fair and pale blue, lovely in newness, and at last the wind was still. Yet the waves broke white in the many rocks, and tore in the shingle of the little bay" [CSN: 581].

A peculiar coexistence of the sun and shadow is indicative of attainment of inner wholeness - knowledge of the soul's darker side. Floristic imagery adds to this: "the little yellow-and-white narcissus sparkling gaily in the rocks" [CSN: 183]. As Gavriel Reisner points out, "Symbolic landscape painting is intrinsic to Lawrence's art. He accomplishes in his writing what he describes, in a kind of illumination of objects, as a bringing forth of the world into fiery reality" [Reisner: 203]. In this novella that kind of symbolism is most succinct and precise.

The feeling of being re-born inevitably colours the landscape:

"He went slowly, staying to look at the pale blue sea like a flower in unruffled bloom, and the white fringes among the rocks, like white rock-flowers, the hollow slopes sheering up high from the shore, grey with olive trees and green with bright young wheat, and set with the white, small villa. All fair and pure in the January morning" [CSN: 583].

Nature might fall under the third type of Jung's classification of rebirths, whereby the being itself does not change but simply comes physically to life again:

"A dim premonition tells us that we cannot be whole without this negative side, that we have a body which, like all bodies, casts a shadow, and that if we deny this body we cease to be threedimensional and become flat and without substance. Yet this body is a beast with a beast's soul, an organism that gives unquestioning obedience to instinct. To unite oneself with this shadow 
is to say yes to instinct, to that formidable dynamism lurking in the background" [Jung, V 7: 30-31].

The Man Who Died is actually placed in a cave, which is also a symbolic Jungian cave:

"Anyone who gets into that cave, that is to say into the cave which everyone has in himself, or into the darkness that lies behind consciousness, will find himself involved in an - at first - unconscious process of transformation. By penetrating into the unconscious he makes a connection with his unconscious contents. This may result in a momentous change of personality in the positive or negative sense. The transformation is often interpreted as a prolongation of the natural span of life or as an earnest of immortality" [Jung, V 9/1: 135-136].

From the Jungian point of view, the final aim of any quest is self-knowledge. Resurrection, the second type of Jungian rebirth, is actualized in the Man Who Died, for he says: "I am going to be Warm again, and I am going to be whole! I shall be warm like the morning. I shall be a man. It doesn't need understanding. It needs newness. She brings me newness"; "Now I am not myself I am something new..." [CSN: 595].

The man's individuation is inextricably connected with the sense of delight of touch with pure nature, when he stays alone in the cave "to see one white-and-gold narcissus bowing wet" and when he says: "This is the great atonement, the being in touch. The grey sea and the rain, the wet narcissus and the woman I wait for, the in- visible Isis and the unseen sun are all in touch, and at one" [CSN: 597]. Besides, with the coming of spring and realization of the changes that it has brought, "the man and the woman were fulfilled of one another, and departure was in the air" [CSN: 598]. This reads as initiation into a new worldly and natural wisdom, oneness of man and nature, man and woman, - and individuation, or gradual separation of the individual consciousness out of the collective unconscious, and as a result - fusion of the conscious and the unconscious elements of the psyche and their harmonization. The central symbolic image in this scene, which accompanies Lawrence's resurrection concept, is the narcissus. In several of his poems ("Narcissus", "God is Born") it appears as a harbinger of a new life:

\section{When from a world of mosses and of ferns} at last the narcissus lifted a tuft of five-point stars and dangled them in the atmosphere,

then every molecule of creation jumped and clapped its hands:

God is born! God is born perfumed and dangling and with a little cup! [CP: 400-401].

The incompleteness of the novella's plot - lack of textually shaped conventional denouement is a clear indication of the infinity, the Faustian yearning for ultimate knowledge, dynamics and change. Gamini Salgado comments: "Furthermore, the union between the man and the woman is presented, in a characteristically Lawrentian 
fashion, as embodying the right relationship between humanity and the non-human forces of life, which we neglect at our peril" [Salgado: 132].

Lawrence the mystic applies the principle of synchronicity, actions of the supernatural forces, powers of a symbolic object and the quest archetype to create the mystical distance in his shorter fiction. The mystical distance reflects the "landscapes of the heart" and may be covered to the point of an exalted fulfillment, complete merger with the spirit of place (like in St Mawr), result in an alienating encounter with a Shadow-Animus (like in The Princess), be a way to death, or the Night-Sea Journey (in The Woman Who Rode Away), and symbolize rebirth (The Escaped Cock). The "Spirit of Place" is the reflection of that part of our collective unconscious, which undergoes initiation and individuation through the mystical quest of the Self.

\section{References}

Balbert, P. (1989). Snake's eye and obsidian knife: art, ideology, and "The Woman Who Rode Away". In P. Balbert (Ed.), D.H. Lawrence and the phallic imagination: essays on sexual identity and feminist misreading. New York: St. Martin's, 109-132.

Consiglio, M.C. (2013). Art and the spirit of place: D.H. Lawrence translates Giovanni Verga. Etudes Lawrenciennes, 44, 111-142.

Deggan, M. (2012). "Nowhere will now say a few words": the aesthetics of landscape in
D.H. Lawrence's Kangaroo. D.H. Lawrence Studies, 20(2), 87-113.

Feyel, J. (2007). The internal travel towards jouissance. Etudes Lawrenciennes, 37, 107-124.

Hawthorn, J. (2001). Studying the novel. New York: Oxford University Press.

Hough, G. (1994). The dark sun. London: Pelican Books.

Jung, C.G. (2014). The collected works of C.G. Jung (H Read et al., Eds., R.F.C. Hull, Trans.) (2nd ed). Princeton, NJ: Princeton UP.

Lawrence, D.H. (2009). Complete poems by Lawrence. UK: ReadHowYouWant (CP).

Lawrence, D.H. (1990). The complete short novels (K. Sager \& M. Partridge, Eds.). London: Penguin Books, 276-428 (CSN).

Lawrence, D.H. (2017). The complete short stories. Delphi Classics (CSS).

Lawrence, D.H. (2002). Th letters of D.H. Lawrence. Volume V: 1924-27 (J. Boulton \& L. Vasey, Eds.). Cambridge: Cambridge University Press.

Lawrence, D.H. (1971). Fantasia of the unconscious and psychoanalysis and the unconscious. London: Penguin (FUPU).

Lawrence, D.H. (2014). Glad ghosts. Pickering: Blackthorn Press (GG).

Lawrence, D.H. (1977). Odour of chrysanthemums and other stories. Moscow: Progress Publishers (OOC).

Lawrence, D.H. (1993). Selected short stories. New York: Dover Publications, Inc., (SSS).

Lawrence, D.H. (2003). Studies in classic American literature (E. Greenspan, L. Vasey \& J. 
Worthen, Eds.). Cambridge: Cambridge University Press (SCAL).

Lawrence, D. H. (1995). The white peacock. London: Penguin Books (WP).

Lawrence, D.H. (2002). The woman who rode away and other stories. Cambridge: Cambridge University Press (WWRA).

Leavis, F.R. (1994). D.H. Lawrence: novelist. London: Penguin.

May, K.M. (1977). Out of the maelstrom. Psychology and the novel in the twentieth century. London: Unwin Brothers Limited.

McCallum, L. (2003). Ritual sacrifice in "The Woman Who Rode Away": a Girardian reading. In K. Cushman \& E. Ingersoll (Eds.), D.H. Lawrence: new worlds. Madison: Fairleigh Dickinson University Press, 230-242.

Moss, G.A. (2015). 'Beginning Rather Than an End': popular culture and modernity in D.H. Lawrence's St. Mawr. Journal of D.H. Lawrence Studies, 4(1), 119-139.

Ragachewskaya, M. (2015). D.H. Lawrence and a new ecological consciousness. D.H. Lawrence Studies. 23(2), 49-69.
Reisner, G. (2003). The death ego and the vital self: romances of desire in literature and psychoanalysis. Cranbury: Associated University Presses.

Salgado, G. (1992). A preface to Lawrence. Hong Kong: Astros Printing Ltd.

Salter, L. (1997). Lawrence and the environment; the poetics of honesty and despair. Etudes Lawrenciennes, 14/15, 75-186.

Schapiro, B.A. (1999). D.H. Lawrence and the paradoxes of psychic life. New York: State University of New York Press.

Schneider, D.J. (1982). D.H. Lawrence, the artist as psychologist. Kansas: The University Press of Kansas.

Stewart, J. (2003). Movement, space, and rhetoric in Lawrence's travel writing. In K. Cushman \& E. Ingersoll (Eds.), D.H. Lawrence: new worlds. Madison, NJ: Fairleigh Dickinson University Press, 151-167.

Storch, M. (1993). "But not the America of the whites": Lawrence's pursuit of the true primitive. D.H. Lawrence Review, 25.1-3, 48-62.

Taylor, S. (2001). Lawrence the mystic. Journal of the D.H. Lawrence Society, 62-74.

Wilson, C. (2009). Superconsciousness. London: Watkins Publishing. 


\section{МИСТИЧЕСКАЯ ДИСТАНЦИЯ В МАЛОЙ ПРОЗЕ Д.Г. ЛОУРЕНСА: ДУХ МЕСТА И ПЕЙЗАЖИ СЕРДЦА}

Марина Станиславовна Рогачевская, доктор филологических наук, профессор Минского государственного лингвистического университета (Минск, Беларусь); e-mail: marinaragachevskaya@gmail.com.

А ннотация. В статье использован юнгианский архетипический подход в анализе

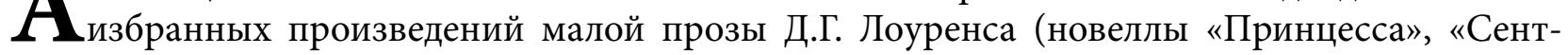
Мавр», «Уехавшая верхом», «Сбежавший петух» и некоторые рассказы), в которых таинственные характеристики места и расстояния/дистанции играют важную роль в повествовании, духовнопсихологическом развитии персонажей, процессе их индивидуации. Выделяются четыре типа мистической дистанции в малой прозе Д.Г. Лоуренса с акцентом на пространственном аспекте анализируемых новелл. В статье показано, что в каждом тексте в разной форме присутствует «дух места» в качестве юнгианских архетипов Духа, Тени, Анимы или Анимуса. Все персонажи проходят духовную трансформацию посредством своего квеста. Эта трансформация осуществляется по-разному, а дистанция, которую они преодолевают, отличается мистическими свойствами. Место служит физической дистанцией квеста персонажей, в то время как душевные движения раскрывают такие формы духовно-мистических аспектов, как Дух-Анимус, Дух-Тень, жертвоприношение и возрождение.

К пючевые слова: Д.Г. Лоуренс, Дух места, мистическая дистанция, архетип, квест, Тень, трансформация, Дух-Анимус, Дух-Тень.

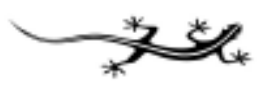

